\title{
Apoptotic and necrotic blebs in epithelial cells display similar neck diameters but different kinase dependency
}

\author{
LF Barros $^{\star, 1,3}$, T Kanaseki ${ }^{2}$, R Sabirov ${ }^{1,2}$, S Morishima ${ }^{1,2}$, \\ J Castro ${ }^{3}$, CX Bittner ${ }^{3}$, E Maeno ${ }^{1,2}$, Y Ando-Akatsuka ${ }^{1,2}$ \\ and $Y$ Okada $^{1,2}$ \\ 1 Department of Cell Physiology, National Institute for Physiological Sciences, \\ School of Life Science, Okazaki, Aichi 444-8585, Japan \\ ${ }^{2}$ CREST of Japan Science and Technology Corporation (JST), Okazaki, Aichi \\ 444-8585, Japan \\ ${ }^{3}$ Centro de Estudios Científicos CECS, Arturo Prat 514, Valdivia, Chile \\ * Corresponding author: LF Barros, Centro de Estudios Científicos CECS, \\ Arturo Prat 514, Valdivia, Chile. Tel: 5663 234500; Fax: 5663 234517; \\ E-mail: fbarros@cecs.cl
}

Received 25.7.02; revised 20.1.03; accepted 23.1.03 Edited by D. Nicholson

\begin{abstract}
Apoptotic and necrotic blebs elicited by $\mathrm{H}_{2} \mathrm{O}_{2}$ were compared in terms of dynamics, structure and underlying biochemistry in HeLa cells and Clone 9 cells. Apoptotic blebs appeared in a few minutes and required micromolar peroxide concentrations. Necrotic blebs appeared much later, prior to cell permeabilization, and required millimolar peroxide concentrations. Strikingly, necrotic blebs grew at a constant rate, which was unaffected throughout successive cycles of budding and detachment. At $1 \mu \mathrm{m}$ diameter, the necks of necrotic and apoptotic blebs were almost identical. ATP depletion was discarded as a major factor for both types of bleb. Inhibition of ROCK-I, MLCK and P38MAPK strongly decreased apoptotic blebbing but had no effect on necrotic blebbing. Taken together, these data suggest the existence of a novel structure of fixed dimensions at the neck of both types of plasma membrane blebs in epithelial cells. However, necrotic blebs can be distinguished from apoptotic blebs in their susceptibility to actomyosin kinase inhibition.
\end{abstract}

Cell Death and Differentiation (2003) 10, 687-697. doi:10.1038/ sj.cdd. 4401236

Keywords: apoptosis; necrosis; blebs; cytoskeleton; ATP; calcium

Abbreviations: $\mathrm{KRH}$, Krebs Ringer Hepes buffer; AVD, apoptotic volume decrease; NVI, necrotic volume increase; PI, propidium iodide; LDH, lactate dehydrogenase .

\section{Introduction}

Blebs are balloon-like, quasi-spherical protrusions of the plasma membrane that are found in association with cell injury. Blebs have also been observed in healthy cultured cells during particular stages of the cell cycle, ${ }^{1,2}$ rapidly expanding within 3-5s and stopping abruptly at diameters of a few micrometers, followed by slow shrinkage. ${ }^{3,4}$ Such 'normal' blebs may play a role in cell locomotion during embryogenesis. ${ }^{5}$ In damaged cells, the presence of blebs correlates with impending cell death but their biological function is not yet known. At the systemic level, blebs may play pathogenic roles; for instance, the blebbed lumenal surface of endothelial cells is a preferential site for platelet aggregation ${ }^{6}$ and monocyte chemotaxis. ${ }^{7}$ Blebs can also carry infective viral particles from liver into the blood, thus becoming an integral part of the pathogenic cycle of needle-transmitted hepatitis. $^{8}$

Notwithstanding their poorly understood role in cell physiology, blebs are receiving renewed attention since they were first recognized as one hallmark of apoptosis. As an early feature in the execution phase, ${ }^{9}$ blebs form inside $30 \mathrm{~min}$ of exposure to diverse apoptotic stimuli, coinciding with channelmediated $\mathrm{K}^{+}$and $\mathrm{Cl}^{-}$loss during a response termed apoptotic volume decrease (AVD). In some cell systems, this precedes mitochondrial cytochrome $c$ release and caspase 3 activation. ${ }^{10,11}$ Blebbing does not seem to mediate the central biochemical events in early apoptosis but their pharmacological inhibition has been correlated with defective formation of apoptotic bodies. ${ }^{12}$ The molecular mechanisms behind apoptotic blebbing are not yet clear, although several recent studies showed involvement of the actomyosin cytoskeleton and its regulators such as the kinases ROCK-I and MLCK. ${ }^{9,12-14}$ In HUVE cells, $\mathrm{CHO}$ cells and also in HeLa cells stimulated with $\mathrm{H}_{2} \mathrm{O}_{2}$, apoptotic bleb formation requires activation of the serine threonine kinase p38MAPK, with the actin-polymerization promoter HSP27 as its likely downstream effector. ${ }^{15-17}$

Necrotic blebs form in cells exposed to more intense noxious stimuli such as hypoxia, metabolic poisoning and high concentrations of free radicals. ${ }^{18}$ Appearing during the last stages of injury prior to cell lysis, necrotic blebs also differ from apoptotic blebs insofar as they grow indefinitely without retraction, reaching diameters of tens of micrometers. In contrast to apoptotic blebs, which coincide with cell volume decrease, necrotic blebbing is associated with cell swelling termed necrotic volume increase (NVI), the execution phase of necrosis characterized by a rapid influx of $\mathrm{Na}^{+}$that in cultured liver cells is partly mediated by non-selective cation channels. ${ }^{19,20}$ There has been no study on the biochemical mechanisms underlying necrotic blebbing, including dependence on ROCK-I, MLCK and p38MAPK. In several previous 
reports, ${ }^{21-23}$ ATP depletion was suggested as a causative factor for necrotic blebs.

To the best of our knowledge, there has been no direct comparison of necrotic and apoptotic blebs. In this study, we triggered the formation of both types of blebs in two epithelial cell types and recorded their dynamics and morphology, their relation with ATP and calcium levels, and their response to pharmacological inhibition of ROCK-I, MLCK, P38MAPK, caspases and calpain. HeLa cells were chosen as they are a well-characterized epithelial system with regard to ion and volume regulation under both normal and stressed conditions. ${ }^{11}$ Liver Clone 9 cells, which have been used in our laboratory for cell death studies, ${ }^{19}$ were chosen for selected experiments to ensure the applicability of the results to other epithelial cells. Hydrogen peroxide, a known bleb inducer, ${ }^{16,24,25}$ was employed, since it is able to trigger both apoptosis and necrosis depending on the concentration used. ${ }^{26}$ Our findings suggest that necrotic and apoptotic blebs are constrained by a common structure located at their necks, although both are distinct in the light of their dependence on actomyosin phosphorylation.

\section{Results}

\section{Apoptotic blebs and necrotic blebs}

In order to carry out a comparative study of necrotic and apoptotic blebs, we first searched for adequate experimental conditions using time-lapse videomicroscopy. In HeLa cells, as in other cell types, ${ }^{16,27}$ hydrogen peroxide induces blebbing and other typical signs of apoptosis like nuclear condensation and fragmentation. ${ }^{1,28}$ Upon exposure to hydrogen peroxide and regardless of the dose used (0.031$32 \mathrm{mM}$ ), HeLa cells reacted with cytoplasmic retraction (Figure 1a,b), consistent with the release stage of the apoptotic execution phase. ${ }^{9}$ This was followed by rapid onset of dynamic blebbing. As was described for 'normal' blebs, ${ }^{1}$ we could elicit these early blebs most efficiently by using newly plated cultures ( $\leq 48 \mathrm{~h}$ since plating; Figure $1 \mathrm{~b}$ ). At $125 \mu \mathrm{M}$ peroxide, these blebs were small, transient, and were followed by a $70 \pm 10 \%(n=11, P<0.05)$ increase in the activity of caspase- 3 and a $33 \pm 4 \%(n=23, P<0.05)$ decrease in cell viability after $6 \mathrm{~h}$. Under identical conditions, caspase-1 activity was not affected $(n=11)$. These dynamic and biochemical features are typical of apoptotic blebbing. ${ }^{16}$

Increasing peroxide up to $32 \mathrm{mM}$ did not change either onset or gross morphology of the blebs but inhibited their full retraction, most likely because of impaired myosin II activity and actin polymerization during ATP depletion (see below). In contrast, older cultures with flatter cells ( $\geq 72 \mathrm{~h}$ since plating) did not display apoptotic blebs, even by peroxide at high millimolar concentrations (Figure 1c), but only developed lateonset blebs (Figure 1d). Since this bleb formation was followed by plasma membrane permeabilization to propidium iodide (PI) and release of cytosolic proteins (Figures 1e, 2d), the late-onset blebs are necrotic. A previous report in epithelial LLC-PK1 cells showed that increasing doses of peroxide accelerate the sequence of necrotic changes without affecting their order of appearance. ${ }^{25}$ Of note, $6 \mathrm{~h}$ after exposure to $32 \mathrm{mM}$ peroxide, $86 \pm 1 \%(n=22)$ of cells under-
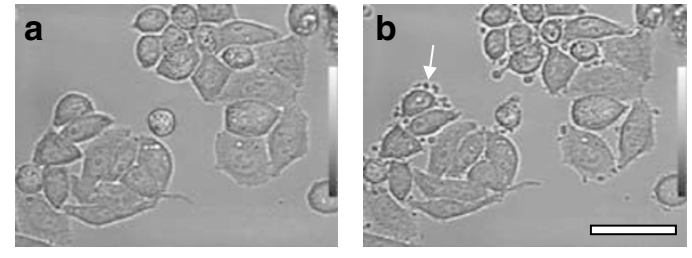

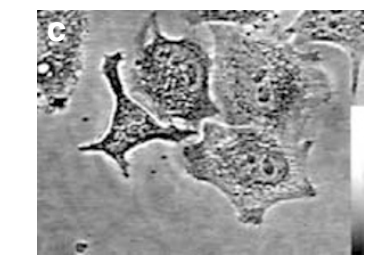

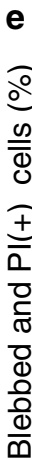

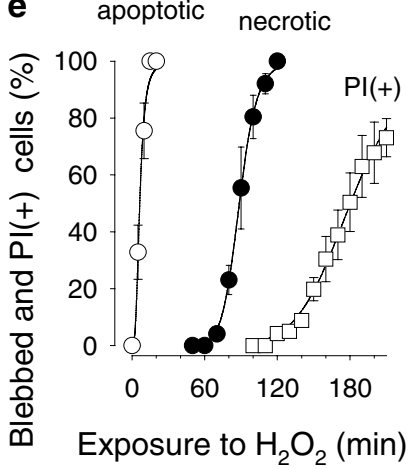

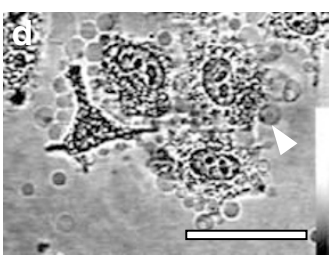

f

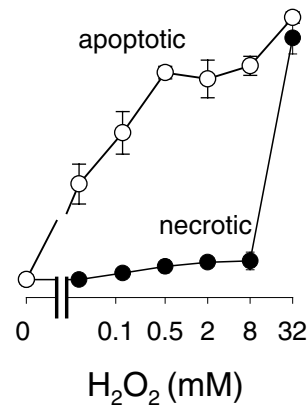

Figure 1 Apoptotic and necrotic blebs in HeLa cells can be distinguished by time of onset and $\mathrm{H}_{2} \mathrm{O}_{2}$ dose dependence. Phase-contrast images of a $48 \mathrm{~h}$ cell culture are shown before (a) and after (b) 20 min exposure to $32 \mathrm{mM} \mathrm{H}_{2} \mathrm{O}_{2}$, where apoptotic blebs are evident (small arrow). A cell culture of $72 \mathrm{~h}$ is shown after $20 \mathrm{~min}$ (c) or $120 \mathrm{~min}$ (d) exposure to $32 \mathrm{mM} \mathrm{H}_{2} \mathrm{O}_{2}$. A necrotic bleb is indicated by a large arrowhead. Gray scales are shown. (e) Onset of apoptotic blebbing (open circles), necrotic blebbing (closed circles) and PI permeabilization (open squares) after exposure to $32 \mathrm{mM} \mathrm{H}_{2} \mathrm{O}_{2}$. Mean \pm S.E.M $(n=3-6)$. (f) $\mathrm{H}_{2} \mathrm{O}_{2}$ concentration dependence of apoptotic bleb induction assessed after $20 \mathrm{~min}$ (open circles) and necrotic bleb induction assessed at $120 \mathrm{~min}$ (closed circles). See text for classification criteria. Mean \pm S.E.M. $(n=4-8)$. Bars are $50 \mu \mathrm{m}$

went cell death because of necrosis but not apoptosis, with no apparent changes in caspase- 3 activity $(-1 \pm 7 \%, n=11)$. This can be explained both by the inhibitory effect of energy depletion on apoptosis ${ }^{29}$ and the reported inhibitory effect of hydrogen peroxide on caspase-3 activation. ${ }^{30}$

As expected from the report by Hampton and Orrenius, ${ }^{26}$ apoptotic blebbing was much more sensitive to $\mathrm{H}_{2} \mathrm{O}_{2}$ than necrotic blebbing (Figure 1f). In order to minimize experimental variables, most experiments were carried out with a single dose of hydrogen peroxide (32 $\mathrm{mM})$ and the two types of blebs were unambiguously distinguished by two major criteria: (i) time of onset (minutes versus hours) and (ii) growth kinetics (transient versus continuous).

A series of experiments was carried out in Clone 9 cells, a nontransformed rat liver epithelial cell line. These very flat cells grow in tight clusters and are not easily imaged under phase-contrast optics, so blebs were visualized and measured by staining the plasma membrane with the fluorescent dyes di-4-ANEPPS and di-8-ANEPPS (Figure 2a-c). As observed with HeLa cells, apoptotic blebs appeared most easily in newly plated cells ( $<1$ day) and required much lower concentrations of peroxide. As with HeLa cells, necrotic 

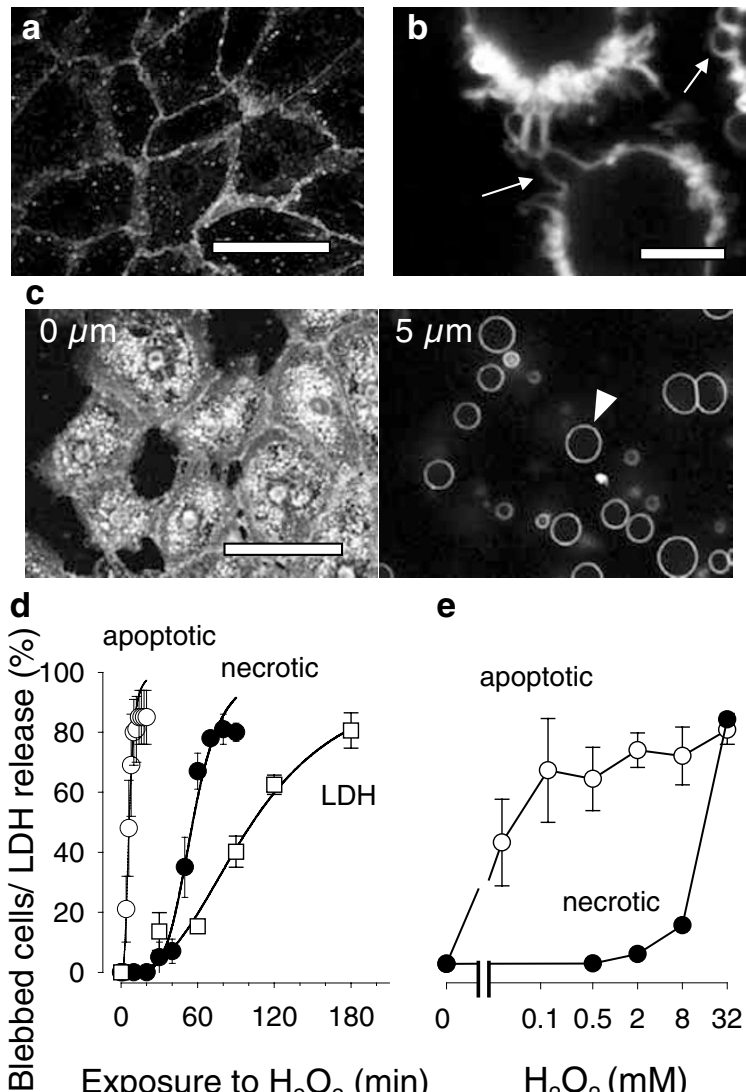

apoptotic

$\mathbf{e}$

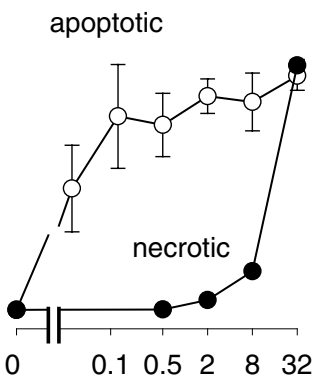

Exposure to $\mathrm{H}_{2} \mathrm{O}_{2}$ (min)

$$
\mathrm{H}_{2} \mathrm{O}_{2}(\mathrm{mM})
$$

Figure 2 Apoptotic and necrotic blebs in Clone 9 cells behave similarly to those from HeLa cells. Lipid membranes in Clone 9 cells were stained for 5 min with $1 \mu \mathrm{g} / \mathrm{ml}$ di-4-ANEPPS (a, c) or $5 \mu \mathrm{g} / \mathrm{ml}$ di-8-ANEPPS (b) and then imaged by confocal microscopy. Optical sections were $2 \mu \mathrm{m}$ thick. (a) Untreated cells. (b) After 20 min exposure to $32 \mathrm{mM} \mathrm{H}_{2} \mathrm{O}_{2}$, where apoptotic blebs are evident (small arrows). (c) Optical sections taken at the level of the cells $(0 \mu \mathrm{m})$ and $5 \mu \mathrm{m}$ above the cells showing several necrotic blebs (arrowhead). (d) Onset of apoptotic blebbing (open circles), necrotic blebbing (closed circles) and LDH release (open squares) after exposure to $32 \mathrm{mM} \mathrm{H}_{2} \mathrm{O}_{2}$. Mean \pm S.E.M. $(n=3-5)$. (e) $\mathrm{H}_{2} \mathrm{O}_{2}$ concentration dependence of apoptotic bleb induction assessed after $20 \mathrm{~min}$ (open circles) and necrotic bleb induction assessed at $60 \mathrm{~min}$ (closed circles). Mean \pm S.E.M. $(n=3)$. Bars are $50 \mu \mathrm{m}$ for $\mathbf{a}$ and $\mathbf{c}$ or $5 \mu \mathrm{m}$ for $\mathbf{b}$

blebbing was only apparent at millimolar peroxide concentrations (Figure 2).

\section{Morphological and kinetical comparisons between apoptotic and necrotic blebs}

Apoptotic blebs appeared soon after exposure to peroxide, with a $t_{1 / 2}$ of $6.4 \pm 0.4 \mathrm{~min}$ in HeLa cells (Figure 1e) and $6.4 \pm 0.3 \mathrm{~min}$ in Clone 9 cells (Figure $2 \mathrm{~d}$ ). They grew for a short period as irregular protrusions that reached up to $10 \mu \mathrm{m}$ maximum diameter. In some cases, blebs were sufficiently spherical to allow accurate estimations of the volume using an automatic system, as illustrated in Figure $3 a$ and described in Material and Methods. Bleb swelling was followed by shrinkage, which could not be quantified as even spherical blebs quickly lost their symmetry (see scanning electron microscopy below). Bleb retraction was not complete and most blebs became small irregular remnants that looked dark a
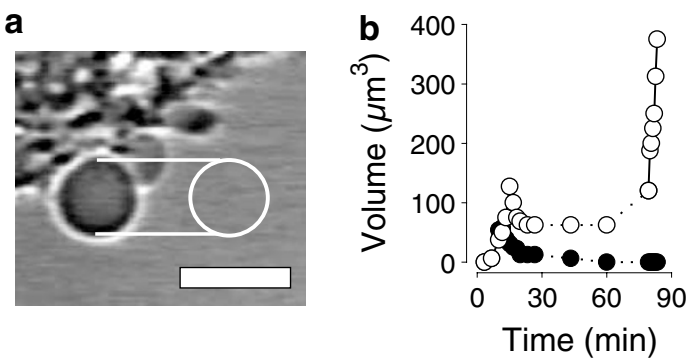

C

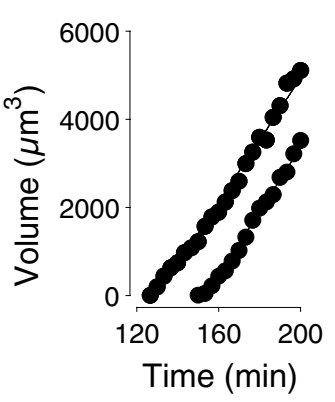

HeLa

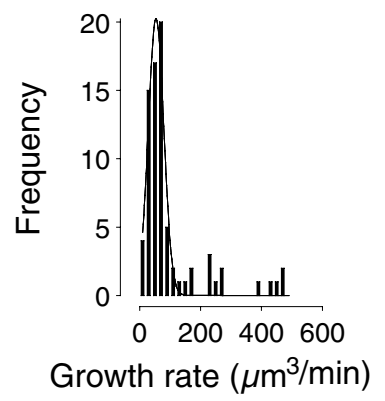

d

\section{Clone 9}
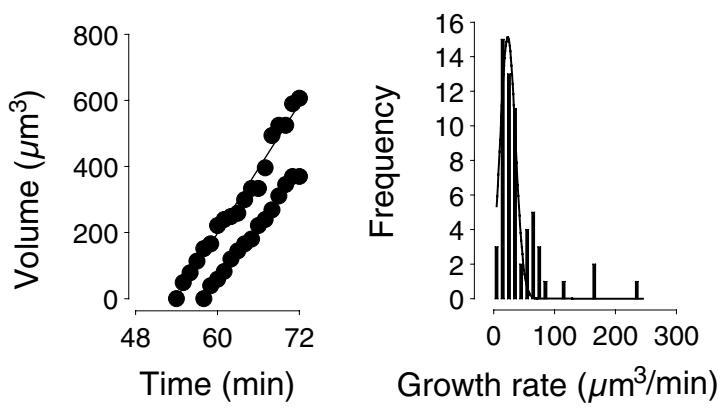

Figure 3 Apoptotic blebs are transient and necrotic blebs grow monotonically in HeLa cells and Clone 9 cells. Blebs were induced at $32 \mathrm{mM} \mathrm{H}_{2} \mathrm{O}_{2}$ and their volume was estimated as described in Material and Methods. (a) The estimated volume of this necrotic bleb in a HeLa cell seen under phase contrast was $180 \mu \mathrm{m}^{3}$. Bar is $10 \mu \mathrm{m}$. (b) Time course of two apoptotic blebs on a single HeLa cell. Dotted lines indicate an approximate estimation as blebs deviated from sphericity. Note that after approximately $80 \mathrm{~min}$ exposure to peroxide, one of the blebs (open circles) restarted growth at a rate of $65 \mu \mathrm{m}^{3} / \mathrm{min}$. (c) The left graph illustrates the time courses of two necrotic blebs on the same HeLa cell, where rates of volume increase were 65 and $67 \mu \mathrm{m}^{3} / \mathrm{min}$. The right panel shows the growth rate distribution of 78 necrotic blebs measured on $30 \mathrm{HeLa}$ cells. The Gaussian fit gave an $X_{0}=54 \pm 2 \mu \mathrm{m}^{3} / \mathrm{min}$. (d) The left graph illustrates the time courses of two necrotic blebs on two neighboring Clone 9 cells, where rates of bleb volume increase were 32 and $25 \mu \mathrm{m}^{3} / \mathrm{min}$. The right panel shows the growth rate distribution of 61 necrotic blebs measured on 40 Clone 9 cells, with an $X_{0}=23 \pm 1.5 \mu \mathrm{m}^{3} / \mathrm{min}$

under phase-contrast optics (Figure 1b). In less than $5 \%$ of the cases, after a lag phase of about $1 \mathrm{~h}$, the shrunken remains regained sphericity and started to grow at constant rates such as that illustrated in Figure $3 \mathrm{~b}$. The timing of the second growth phase was coincidental with both the onset of necrotic blebs at other locations of the cell surface and the onset of necrotic blebs in cells that had not presented apoptotic blebs at all.

Necrotic blebs were routinely studied in cells that had not displayed apoptotic blebs, as judged by the maximum resolution of our imaging system (approximately $0.2 \mu \mathrm{m}$ ). In 
HeLa cells, they appeared after 60 min exposure to peroxide, with a $t_{1 / 2}$ of $89 \pm 6 \mathrm{~min}$, which was followed by cell permeabilization to $\mathrm{PI}$ (necrosis) with a $t_{1 / 2}$ of $180 \pm 8 \mathrm{~min}$ (Figure 1e). Bleb development was not because of a direct effect of $\mathrm{H}_{2} \mathrm{O}_{2}$, as HeLa cells that were transiently exposed for only $60 \mathrm{~min}$ formed necrotic blebs with a similar $t_{1 / 2}$ of $89 \pm 16 \mathrm{~min}$. In marked contrast to apoptotic blebs whose growth was irregular and short-lived, necrotic blebs grew monotonically throughout observation periods of over $30 \mathrm{~min}$ (Figure 3c). When two or three blebs could be focused in the same cell, growth rates were found to be almost identical (Figure 3c; see also Figure 4). Moreover, data from a large number of cells from several separate experiments showed that even though blebs grew at rates varying more than 10fold between 30 and $500 \mu \mathrm{m}^{3} / \mathrm{min}$, most of them distributed tightly around a typical growth rate of $54 \pm 2 \mu \mathrm{m}^{3} / \mathrm{min}$ (Figure $3 \mathrm{c}$, right panel). Observed for longer periods after $\mathrm{PI}$ permeabilization, blebs eventually stopped growing or lost their spherical shape to suddenly coalesce into large blisters that could reach up to $80 \mu \mathrm{m}$ diameter (not shown). Similar behavior was observed in Clone 9 cells with necrotic blebs growing linearly, but to rates approximately half of that measured in HeLa cells, averaging $23 \pm 1.5 \mu \mathrm{m}^{3} / \mathrm{min}$ (Figure 3d).
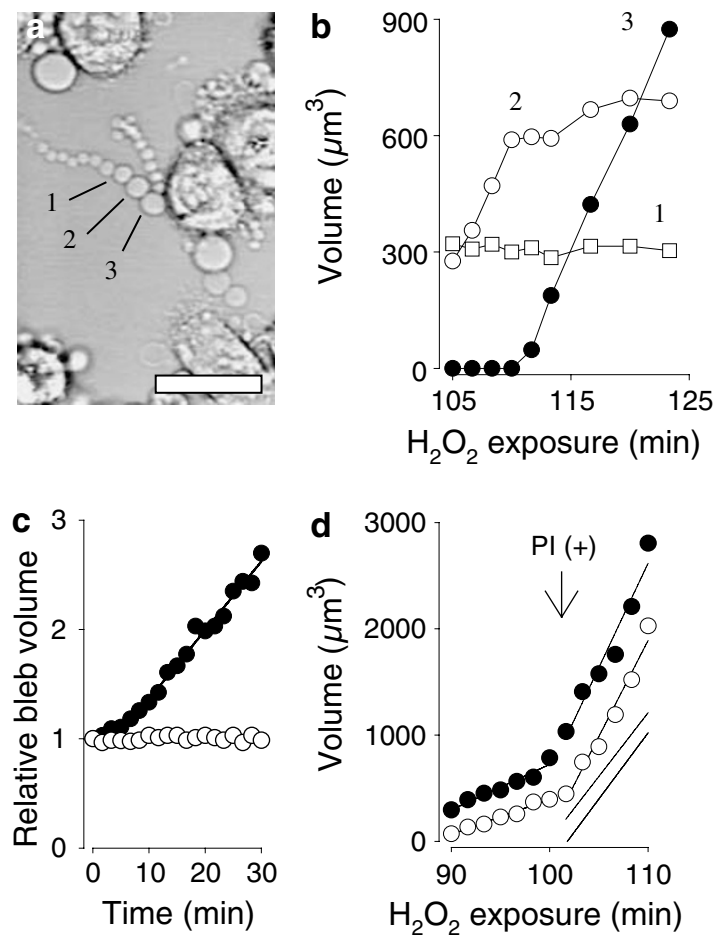

Figure 4 Dynamics of necrotic bleb growth and shedding. (a) DIC image of HeLa blebs measured in (b) at 125 min exposure to $32 \mathrm{mM} \mathrm{H}_{2} \mathrm{O}_{2}$. Bar is $30 \mu \mathrm{m}$. (b) Measurements started after $105 \mathrm{~min}$ exposure to peroxide. Rates of volume increase were $63 \mu \mathrm{m}^{3} / \mathrm{min}$ (bleb 2, open circles; $105-110 \mathrm{~min}$ ) and $67 \mu \mathrm{m}^{3} / \mathrm{min}$ (bleb 3, closed circles; 112-124 min). (c) Relative volume change of two blebs from a single HeLa cell. One bleb detached at time zero (open symbols), while the other kept attached (closed symbols). (d) Simultaneous observations of growing kinetics of two blebs present on a single HeLa cell and PI staining of the nucleus of the cell after $90 \mathrm{~min}$ of peroxide exposure. In addition to two original blebs (open and closed symbols), two other blebs were found upon the onset of PI permeabilization in the same cell and started to grow (lines without symbols)
As a result of their tense appearance and their content rich in ribosomes, blebs are thought to grow mostly driven by hydrodynamic forces that eject cytosolic material from the cell body. ${ }^{3}$ The observation in HeLa cells illustrated in Figure 4a and $b$ lends further support to such a notion. In this experiment, a cell was decorated by a chain of nine blebs, the most proximal of which was growing at a constant rate of $63 \mu \mathrm{m}^{3} / \mathrm{min}$, whereas the second bleb in the chain had stalled at $300 \mu \mathrm{m}^{3}$. After $5 \mathrm{~min}$, a tenth bleb formed at the beginning of the chain, and acquired a constant rate of $67 \mu \mathrm{m}^{3} / \mathrm{min}$ whereas, the bleb displaced to the second place in the chain stopped growing. In other experiments, blebs were observed spontaneously to detach, events that were always followed by growth stagnation (Figure 4c), confirming that blebs fill up by hydrodynamic flow of cytosolic material from the cell body. The fact that the newly budded bleb acquired a growth rate identical to that of the previous one suggests the presence of a permanent structure at its base, a structure resilient enough to withstand both bleb budding and bleb detachment.

To examine the relation between necrotic bleb growth and cell permeabilization, both were simultaneously recorded in a HeLa cell from which only two blebs were growing after 90 min exposure to peroxide. As shown in Figure 4d, cell permeabilization monitored by $\mathrm{PI}$ staining of the nucleus related to an increase in the growth rate $\left(\mu \mathrm{m}^{3} / \mathrm{min}\right.$ ) from 46 (closed symbols) and 53 (open symbols) to 104 and 117, respectively, inflection that correlated with the simultaneous onset of two other blebs in the same cell (lines without symbols). This growth rate increase might be induced by an increase in intracellular hydrostatic pressure likely associated with $\mathrm{PI}$ permeabilization.

Next, HeLa cells were examined using scanning electron microscopy. The results, illustrated in Figures $5 \mathrm{a}-\mathrm{c}$ and summarized in Figure $5 \mathrm{~d}$, show that blebs were connected to their progenitor cell by necks of a standard dimension, with an average diameter of $1.1 \mu \mathrm{m}$. In this sample, $75 \%$ of the blebs displayed necks between 1.0 and $1.2 \mu \mathrm{m}$ diameter despite their volume ranging from 1.7 to $268 \mu \mathrm{m}^{3}$. Surprisingly, measurements of apoptotic bleb were also found to concentrate about a typical diameter, which was also $1.1 \mu \mathrm{m}$ (Figures $5 e-g)$. Apoptotic and necrotic bleb necks in Clone 9 cells were measured using di-8-ANEPPS staining and found also to concentrate around a typical value of $1 \mu \mathrm{m}$ (Figure 6). These data demonstrate that both apoptotic and necrotic blebs have identical neck diameters in two different cell types, strongly suggesting the existence of a canonical ring structure located at the neck.

Necrotic blebs are driven by net gain of sodium and water. ${ }^{11,20}$ Therefore, we mimicked this force by giving cells hypotonic shock at various times after exposure to $\mathrm{H}_{2} \mathrm{O}_{2}$ and found that the onset of necrotic blebbing was brought forward almost to the same time course determined for apoptotic blebs, as shown in Figure $7 \mathrm{a}$. These results suggest that intracellular hydrostatic pressure upon osmotic cell swelling serves as a driving force to generate necrotic blebs when cells were exposed to peroxide. In the absence of $\mathrm{H}_{2} \mathrm{O}_{2}$, however, HeLa cells subject to a rapid increase in hydrostatic pressure by a severe hypotonic shock did not form blebs but swelled homogeneously (Figure $7 \mathrm{~b}$ and $\mathrm{c}$ ). Therefore, blebbing needs not only increased intracellular pressure but also an additional 

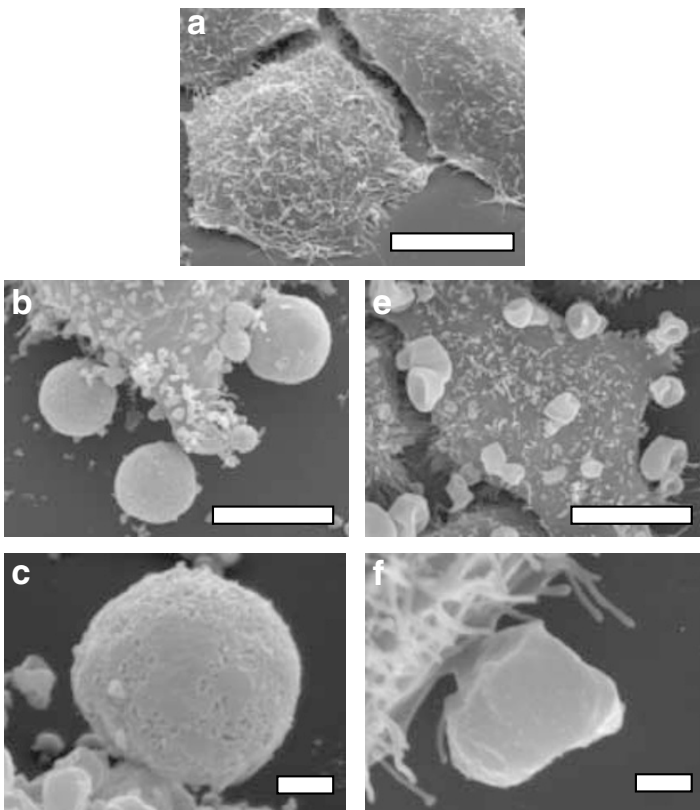

d

necrotic
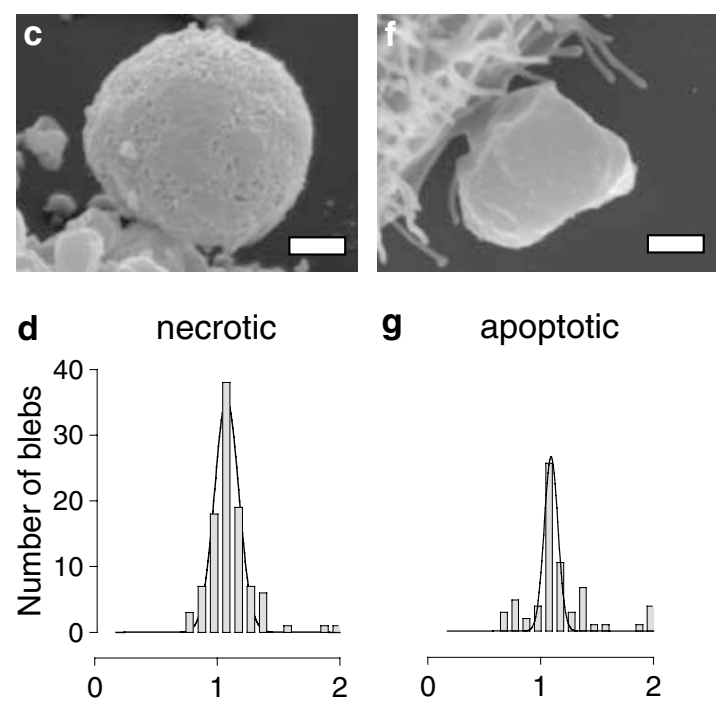

g

apoptotic

Bleb neck diameter $(\mu \mathrm{m})$

Figure 5 Necrotic and apoptotic blebs display similar neck diameters in HeLa cells. After experimental treatments HeLa cells were fixed, stained and imaged under scanning electron microscopy, as described in Material and Methods. (a) Control. (b, c) Necrotic blebs after $90 \mathrm{~min}$ exposure of $72 \mathrm{~h}$ old cultures to $32 \mathrm{mM}$ $\mathrm{H}_{2} \mathrm{O}_{2}$. (d) Frequency distribution of neck diameters is given for 102 necrotic blebs. (e, f) Apoptotic blebs at 20 min exposure of $36 \mathrm{~h}$ cultures to $32 \mathrm{mM} \mathrm{H}_{2} \mathrm{O}_{2}$. (g) Frequency distribution of neck diameters is given for 70 apoptotic blebs. Bars are $10 \mu \mathrm{m}$ in $(\mathbf{a}, \mathbf{b}, \mathbf{e})$ and $1 \mu \mathrm{m}$ in $(\mathbf{c}, \mathbf{f})$. Gaussian fits gave $X_{0}$ values of $1.08 \pm 0.007 \mu \mathrm{m}$ for necrotic blebs and $1.09 \pm 0.01 \mu \mathrm{m}$ for apoptotic blebs

event(s) induced by $\mathrm{H}_{2} \mathrm{O}_{2}$, and is consistent with the notion that blebbing requires the concourse of increased intracellular pressure and a defect in membrane-cytoskeleton attachments. $^{9,13}$

\section{Biochemical determinants of apoptotic and necrotic blebbing}

Studies in several tissues and cell lines exposed to noxas have shown that necrotic blebbing is preceded by a severe depletion of ATP, ${ }^{21-23}$ and a causative role for ATP depletion has been generally deemed. Exposure of HeLa cells to necrotic doses of hydrogen peroxide resulted in a rapid drop of ATP, with a $t_{1 / 2}$ of $2.0 \pm 0.3 \mathrm{~min}$ (Figure 8a) and falling to levels undetectable by $15 \mathrm{~min}$ exposure. Similar rates of depletion were measured in cultures from 24 and $120 \mathrm{~h}$ (not shown).

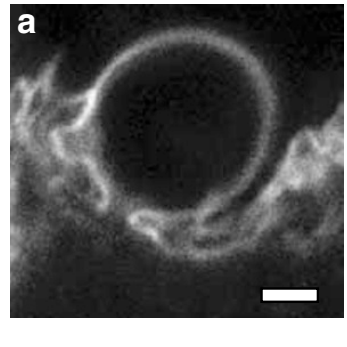

c

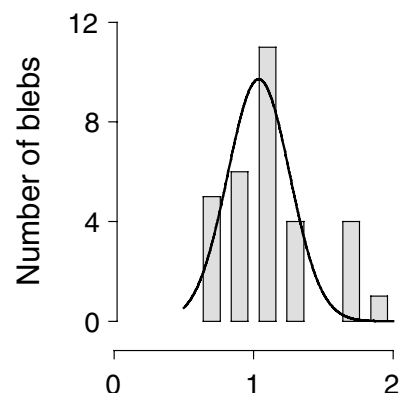

Bleb neck diameter $(\mu \mathrm{m})$

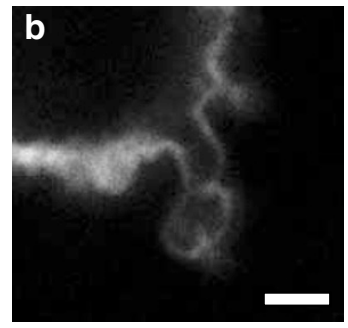

d apoptotic

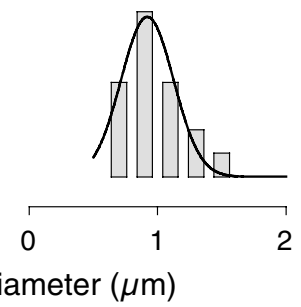

Figure 6 Necrotic and apoptotic blebs display similar neck diameters in Clone 9 cells cells. After experimental treatments, Clone 9 cells were stained by a $20 \mathrm{~s}$ exposure to $5 \mu \mathrm{g} / \mathrm{ml}$ di-8-ANEPPS and immediately imaged by confocal microscopy as described in Material and Methods. Confocal sections were $<0.8 \mu \mathrm{m}$ thick. (a) Necrotic bleb observed after $60 \mathrm{~min}$ exposure of $72 \mathrm{~h}$ old cultures to $32 \mathrm{mM} \mathrm{H}_{2} \mathrm{O}_{2}$. (b) Apoptotic bleb induced by 20 min exposure of 1-dayold culture to $32 \mathrm{mM} \mathrm{H}_{2} \mathrm{O}_{2}$. Bars are $2 \mu \mathrm{m}$. (c,d) Frequency distribution of neck diameters is given for 31 necrotic blebs and 18 apoptotic blebs. Gaussian fits gave $X_{0}$ values of $1.04 \pm 0.05 \mu \mathrm{m}$ for necrotic blebs and $0.92 \pm 0.02 \mu \mathrm{m}$ for apoptotic blebs

ATP depletion by peroxide required much higher doses than those capable of forming apoptotic blebs (Figure 8b), which is in agreement with a large body of evidence that discards ATP depletion as a contributing factor in early apoptosis. ${ }^{29}$ In Clone 9 cells, peroxide exposure resulted in ATP depletion with a similar time course as shown both by a radioenzymatic assay and the increase in free $\mathrm{Mg}^{2+}$ (Castro $\mathrm{J}$ and Barros LF, unpublished data). The approximate $45 \mathrm{~min}$ delay between full ATP depletion and necrotic bleb onset made us suspect that this was not a major or at least a sufficient factor for this kind of bleb either. To test the point, a series of metabolic poisons were tested for their ability to dissociate metabolic energy depletion and bleb formation. The results of such an experiment are illustrated in Figure $9 a$ and $b$, which shows that severe depletion of ATP with a cocktail of 2-deoxyglucose and FCCP did not result in bleb formation, while a milder ATP depletion by a short exposure to $\mathrm{H}_{2} \mathrm{O}_{2}$ was effective. Therefore, ATP depletion does not play a direct role in either apoptotic or necrotic bleb formation in HeLa cells.

A rise in cytosolic $\mathrm{Ca}^{2+}$ has been proposed to participate in bleb formation under oxidative stress. ${ }^{31}$ In HeLa cells, exposure to $32 \mathrm{mM}$ peroxide elicited a limited rise in cytosolic calcium with a $t_{1 / 2}$ of $1.6 \pm 0.4 \mathrm{~min}$, which reached a plateau of $1.9 \pm 0.1$-fold $(n=4)$ after $10 \mathrm{~min}$ (Figure 10a). In the presence of $10 \mathrm{mM}$ EGTA, calcium rose with a $t_{1 / 2}$ of $1.4 \pm 0.3 \mathrm{~min}$, reaching a plateau of $2.2 \pm 0.3$-fold $(n=4)$ after $10 \mathrm{~min}$, showing that most of the divalent cation is released from 


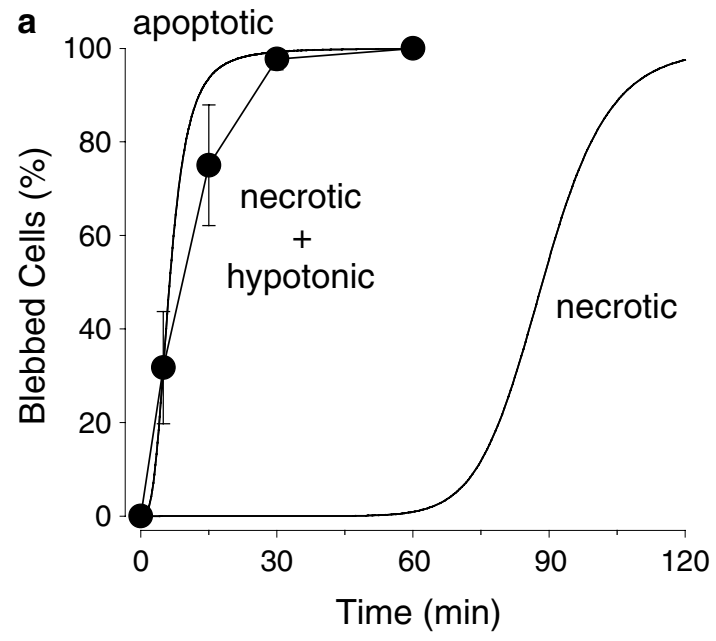

b isotonic

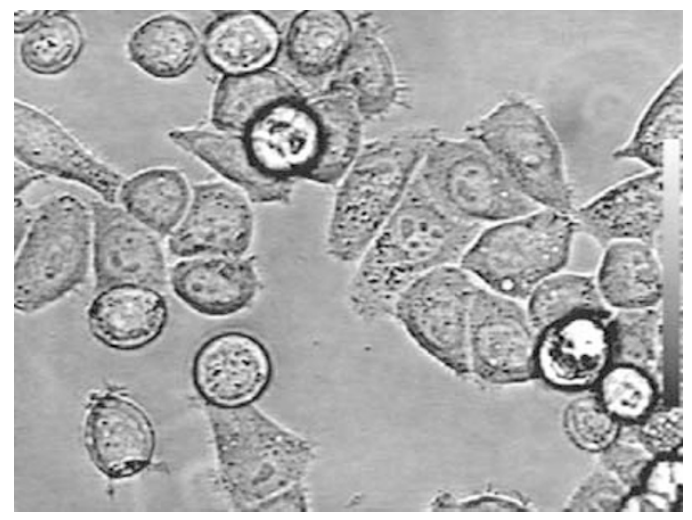

c hypotonic

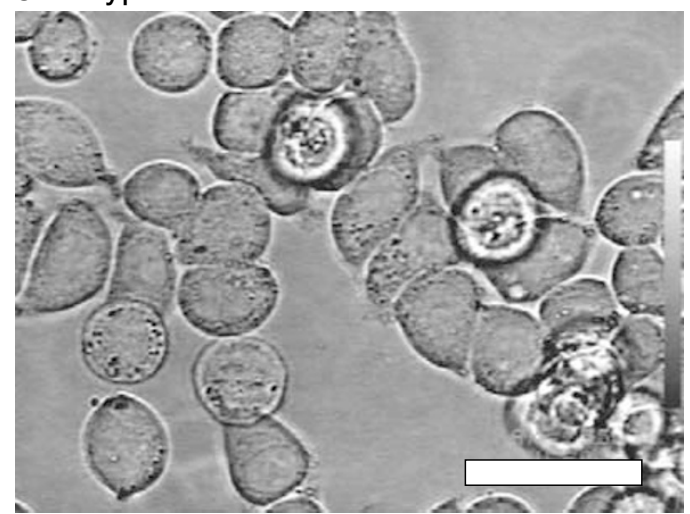

Figure 7 Necrotic bleb onset can be brought forward by increased intracellular pressure. (a) Flat HeLa cells were exposed to $32 \mathrm{mM}$ peroxide for the times shown and then exposed for $1 \mathrm{~min}$ to a 1: 4 dilution of $\mathrm{KRH}$ in water $(25 \%$ of isotonicity) before counting the number of cells displaying necrotic blebs (closed symbols). The fitted time courses of apoptotic and necrotic bleb onset (from Figure 1e) are plotted as references (lineplots without symbols). A parallel batch of cells was checked for their lack of apoptotic bleb formation during 60 min exposure to $32 \mathrm{mM} \mathrm{H}_{2} \mathrm{O}_{2}$. (b,c) A field of untreated HeLa cells was imaged under phase contrast before (b) and after (c) a 10 min exposure to a 1:10 dilution of $\mathrm{KRH}$ in water ( $10 \%$ of isotonicity). Note that cells swelled homogeneously without forming blebs. Gray scales are shown. Bar is $50 \mu \mathrm{m}$

intracellular stores. This is consistent with observations in PD388D1 cells ${ }^{27}$ and Clone 9 liver cells (Castro $\mathrm{J}$ and Barros LF, unpublished data). Since cytosolic calcium increased

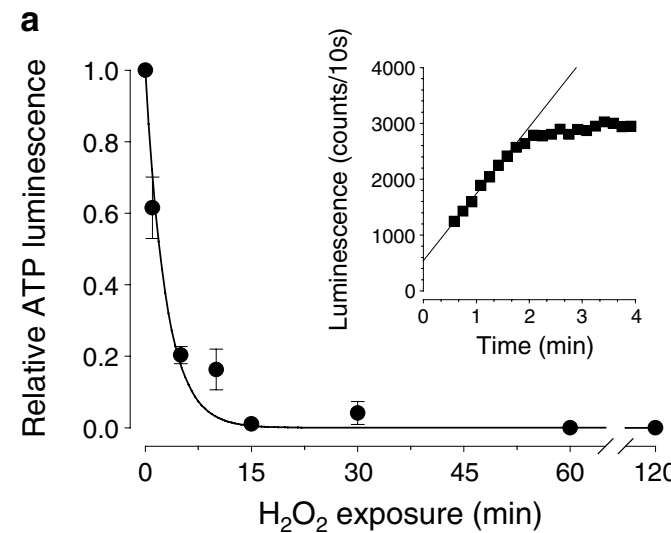

b

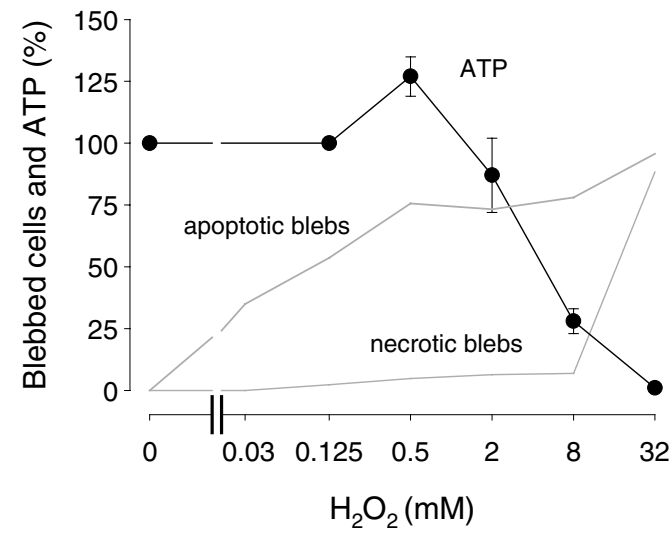

Figure 8 Apoptotic bleb formation is not related to ATP depletion. ATP was measured in 48-72 $\mathrm{h}$ cultures of luciferase-expressing HeLa cells as described in Material and Methods. (a) After exposure for various times to $32 \mathrm{mM} \mathrm{H}_{2} \mathrm{O}_{2}$, cells were washed in buffer containing $250 \mathrm{U} / \mathrm{ml}$ catalase. After washing, lumeniscence was found to recover linearly; which allowed estimation of the original value by extrapolation, the inset shows an example of the procedure from one of the $10 \mathrm{~min}$ points. Mean + S.E.M. $(n=3-6)$. (b) Increasing doses of peroxide were applied for $60 \mathrm{~min}$, cells were then washed with $250 \mathrm{U} / \mathrm{ml}$ catalase and their luminescence recorded directly. Mean + S.E.M. $(n=3)$. Dose-response curves of apoptotic and necrotic blebs from Figure $1 f$ are included for comparison (lineplots without symbols)

before the onset of apoptotic blebbing and bleb formation has been related to calcium increases in hypoxic endothelial cells, ${ }^{32}$ we further investigated its possible role by determining the dose-response curve of calcium increase by peroxide. However, Figure 10b shows that much higher doses of peroxide were required to increase calcium than to induce apoptotic blebbing, so it appears unlikely that cytosolic calcium is involved here.

Also, a negative result was achieved with a calpain inhibitor PD150606 (Figure 11), suggesting that both apoptotic and necrotic blebs are independent of calpain in both HeLa and Clone 9 cells. This result is at variance with observations that calpain inhibitors efficiently blocked necrotic bleb formation induced by tert-butylhydroperoxide in hepatocytes ${ }^{33}$ and by antimycin A in kidney cells. ${ }^{34}$

We next observed effects of a pancaspase inhibitor on both apoptotic and necrotic blebs. Apoptotic bleb formation had been found to be sensitive to a caspase blocker in some cells ${ }^{12,14,35,36}$ but not in others. ${ }^{17,37,38}$ Caspase sensitivity of 
a
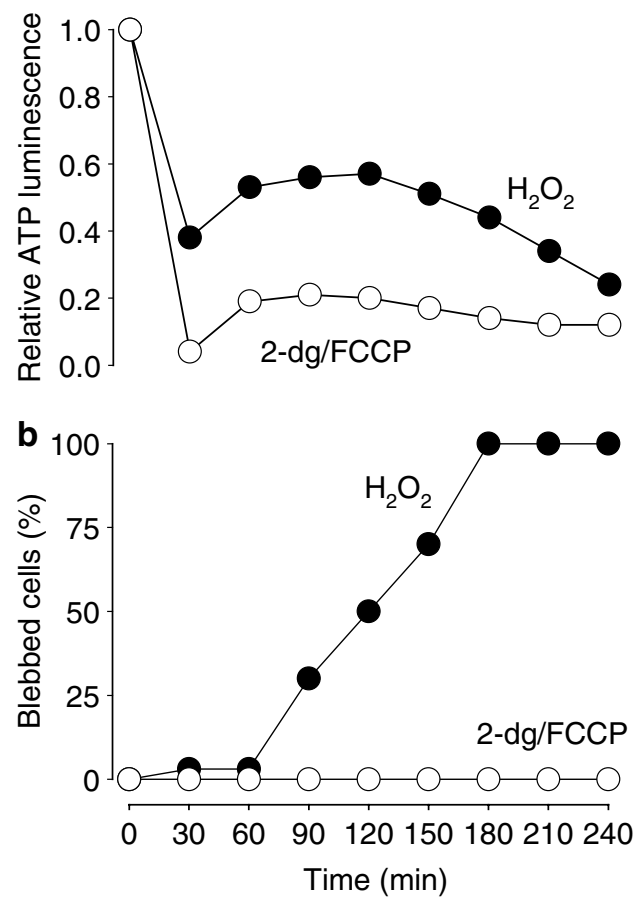

Figure 9 ATP depletion is not sufficient for necrotic bleb formation. (a) After registering basal luminescence, HeLa cells were exposed for $15 \mathrm{~min}$ to $32 \mathrm{mM}$ $\mathrm{H}_{2} \mathrm{O}_{2}$ and washed with $250 \mathrm{U} / \mathrm{ml}$ catalase. Luminescence was then recorded every $30 \mathrm{~min}$ (closed symbols). Other cells were continuously exposed to $10 \mathrm{mM}$ 2-deoxyglucose/1 $\mu \mathrm{M}$ FCCP (open symbols). (b) Bleb formation was assessed in parallel by videomicroscopy. At the end of the experiment ( $240 \mathrm{~min}), 12 \%$ of $\mathrm{H}_{2} \mathrm{O}_{2}$-treated cells and $15 \%$ of the deoxyglucose/FCCP-treated cells were $\mathrm{PI}(+)$. Similar results were obtained in a separate experiment

necrotic bleb formation has never been reported. As summarized in Figure 11, the potent and specific pancaspase inhibitor Z-VAD-fmk was very effective at inhibiting apoptotic bleb formation in HeLa cells but was without any effect on Clone 9 cells. In both cell types, pancaspase inhibition was without effect on necrotic bleb formation.

There have been several reports linking specific signaling pathways with apoptotic blebbing. In HeLa cells, $\mathrm{CHO}$ cells and endothelial HUVE cells, p38MAPK activity was shown to be required for apoptotic bleb formation by hydrogen peroxide. ${ }^{16,17}$ In Jurkat lymphoid cells and NIH 3T3 fibroblast cells, a role was proposed for ROCK-I, ${ }^{12-14}$ while in several cell types MLCK appears to be required. ${ }^{38,39}$ The specific mechanisms involved are unknown, but it was proposed that phosphorylation of cytoskeletal proteins like myosin II leads to production of force, which combined with a putative failure of membrane/cytoskeletal attachments causes blebbing. Figure 11 shows that in both HeLa and Clone 9 cells, apoptotic bleb induction was indeed significantly inhibited by p38MAPK inhibition and also by inhibitors of the ROCK-I and MLCK. In contrast, necrotic blebs were refractory to kinase inhibition. These data suggest that apoptotic bleb formation is a phosphorylation-dependent active process involving p38MAPK, ROCK-I and MLCK, whereas necrotic blebs are independent of these kinases, and also independent of caspase activity and intracellular ATP depletion.
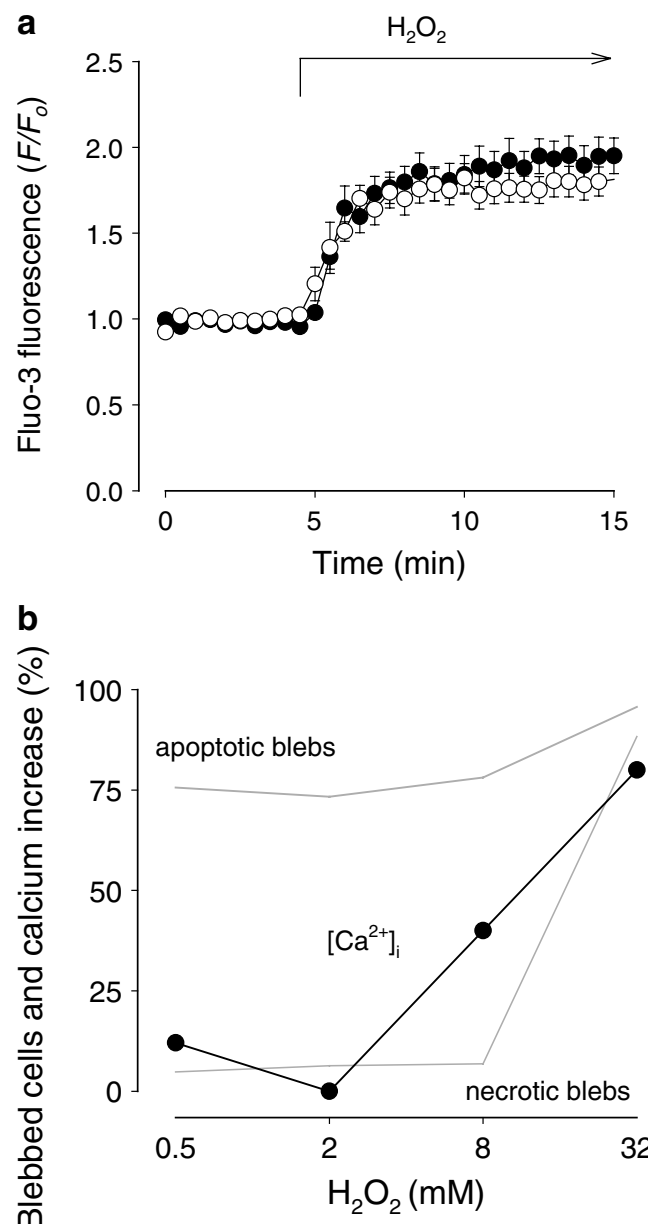

Figure 10 Cytosolic calcium increase does not mediate apoptotic blebbing. (a) Fluo-3 loaded HeLa cells were exposed to $32 \mathrm{mM} \mathrm{H}_{2} \mathrm{O}_{2}$ in $\mathrm{KRH}$ (open symbols) or in $\mathrm{KRH}$ supplemented with $10 \mathrm{mM}$ EGTA (closed symbols). Mean \pm S.E.M. ( $n=8$ cells). (b) Fluo-3 fluorescence changes (\%) were measured after $10 \mathrm{~min}$ exposure of HeLa cells to increasing concentrations of peroxide $(0.5-32 \mathrm{mM})$. Errors are smaller than symbols. Dose-response curves of apoptotic and necrotic blebs from Figure if are included for comparison (lineplots without symbols)

\section{Discussion}

Membrane blebs appear when actin attachments between plasma membrane and the underlying cytoskeleton are weakened. ${ }^{22,40}$ During necrosis, this is thought to occur mainly by ATP depletion without a significant role for calcium, ${ }^{22,41,42}$ although the latter is still discussed. ${ }^{32}$ For apoptotic blebs, several mechanisms have been proposed, which include cleavage and phosphorylation of cytoskeletal proteins. ${ }^{9}$ A novel result presented in this report suggests that in HeLa cells exposed to oxidative stress, both kinds of blebs are constrained by a cytoskeletal structure that localizes at the cell surface and confers blebs a typical neck diameter and a constant swelling rate. As jugded by the finding of constant rates of necrotic bleb swelling also in Clone 9 cells, it appears that such putative structure is not confined to a single cell type. This structure is stable enough to keep its integrity through periods of over $30 \mathrm{~min}$ in high calcium/near zero ATP, withstanding extensive membrane rearrangements during 
HeLa
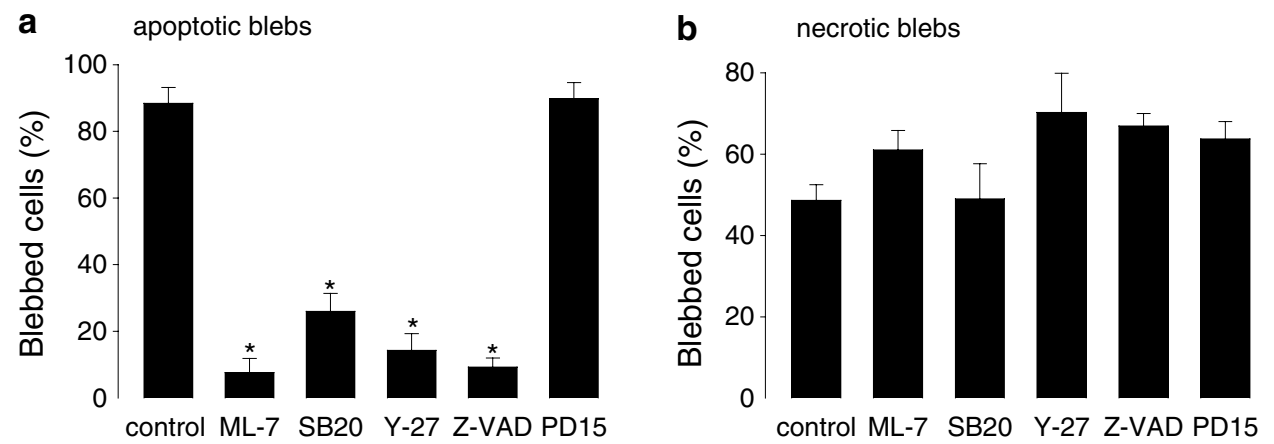

Clone 9
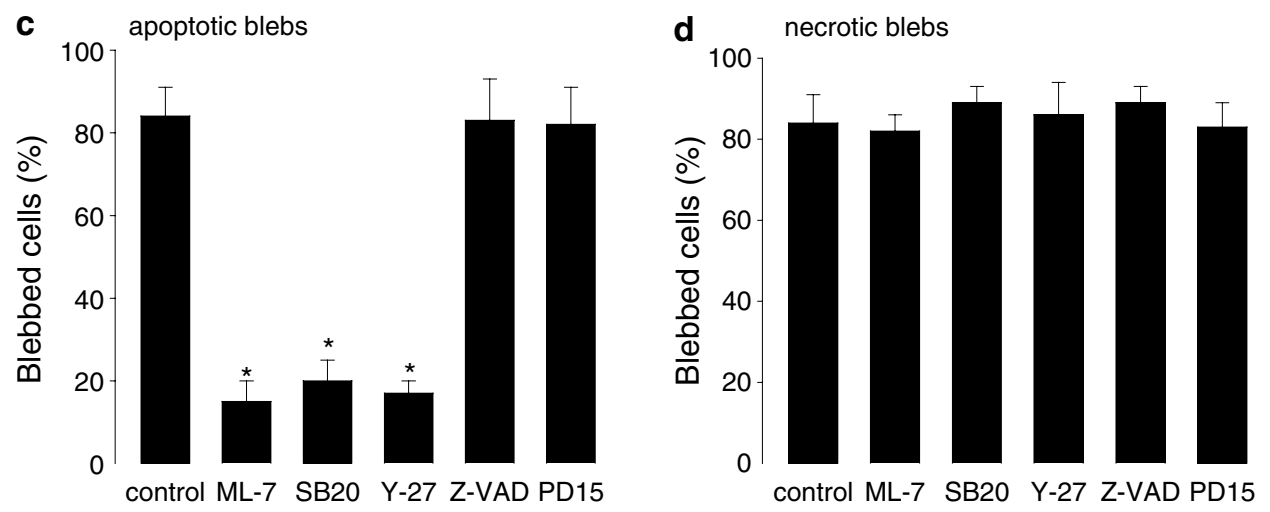

Figure 11 Apoptotic blebs but not necrotic blebs are sensitive to pharmacological inhibition of MLCK, p38MAPK and ROCK-I in HeLa cells and Clone 9 cells. (a) HeLa cells were preincubated for 20 min with $5 \mu \mathrm{M} \mathrm{ML-7} \mathrm{(MLCK} \mathrm{inhibitor),} 10 \mu \mathrm{M}$ SB203580 (p38MPK inhibitor), $10 \mu \mathrm{M}$ Y-27632 (ROCK-I inhibitor), $50 \mu \mathrm{M} z-V A D-f m k$ (pancaspase inhibitor) or $5 \mu \mathrm{M}$ PD150606 (calpain inhibitor), and then exposed for 20 min to $32 \mathrm{mM} \mathrm{H}_{2} \mathrm{O}_{2}$ in the continuous presence of the inhibitors. (b) HeLa cells were preincubated as in a and then exposed for $90 \mathrm{~min}$ to $32 \mathrm{mM} \mathrm{H}_{2} \mathrm{O}_{2}$. (c,d) Identical experiments were carried out with Clone 9 cells. Mean \pm S.E.M. $(n=3-7)$. ${ }^{\star} P<0.05$ with respect to control by ANOVA/Newman-Keuls

repetitive budding and shedding. In addition, it was found in HeLa cells that at $1.1 \mu \mathrm{m}$ the typical neck diameter was similar for apoptotic and necrotic blebs, which with the early formation of necrotic blebs in hypotonically shocked cells makes it feasible that both types of blebs are constrained by the same structure.

Assuming that blebs are filled from the cell body, flow through their base $(F)$ will depend on the average velocity of the material $(V)$ and the cross-sectional area at the base $(A)$, $F=V A$. Following Bernoulli's principle of fluid energy conservation, velocity will in turn be given by $V=\left(2 \rho\left(P_{\mathrm{c}}-P_{\mathrm{b}}\right)\right)^{1 / 2}$, where $\rho$ is density, $P_{\mathrm{c}}$ is the hydrostatic pressure inside the cell and $P_{\mathrm{b}}$ is the hydrostatic pressure inside the bleb. In principle, a constant flow could be given by reciprocal changes in $\Delta P$ and $A$ during the growth. Both scanning electron microscopy and confocal microscopy provided evidence that $A$ is constant. Since $V$ was found to be constant during the growth of necrotic blebs, $\left(P_{\mathrm{c}}-P_{\mathrm{b}}\right)$ must also be constant. Thus, it is suggested that such standing hydrostatic pressure, which is presumably induced by a persistent influx of ions and water, plays an essential role in the formation and growth of necrotic blebs. In this light, the different average rates of bleb growth observed in HeLa and Clone 9 cells implies that these two epithelial cell types regulate their intracellular pressure at different levels.
The molecular components of the putative neck structure are unknown but several candidates may have been described already. F-actin increases after exposure to $\mathrm{H}_{2} \mathrm{O}_{2}$ (27) and is present at the base of the blebs during apoptosis. ${ }^{43,44}$ In endothelial cells tyrosine phosphorylation of cortactin, an $\mathrm{F}$-actin-binding protein, is required for $\mathrm{H}_{2} \mathrm{O}_{2}$ induced blebbing and is also found in the blebs themselves. ${ }^{24}$ Also, transmission electron microscopy of thyroid cells showed the assembly of 6-nm microfilaments at the base of the blebs, ${ }^{45}$ and confocal sectioning of suprastimulated pancreatic cells showed that actin and myosin II localized at the basolateral membrane leaving breaks centered at the neck of the blebs. ${ }^{39}$ The lack of effect of p38MAPK, ROCK-I and MLCK inhibition on necrotic blebbing, together with the total depletion of ATP at that late stage, indicates that these kinases do not participate either in the weakening of cytoskeletal links at the plasma membrane or in the structure of the putative ring that constrains the necrotic blebs. As these kinases can all mediate force generation, ${ }^{9,12-15,17}$, we suggest that the two types of blebs differ only in their driving force. In apoptosis, intracellular pressure is generated by kinase-mediated cytoskeletal contraction, while in necrosis the increase in intracellular pressure is because of unopposed influx of ions and water. Under normal conditions, intracellular hydrostatic pressure is balanced by membrane tension, which 
is supported by underlying cytoskeletal meshwork. During necrosis, hydrostatic pressure may not be adequately balanced by membrane tension in some localized regions, where blebs grow, presumably because of cytoskeletal dysfunction.

A detailed mapping of the signaling events behind apoptotic blebbing, which would also require determination of enzyme activities, is beyond the scope of the present paper. As suggested by their sensitivity to inhibitors, apoptotic blebbing in both cell types may require concurrency of at least three protein kinases that are known to modulate the actomyosin cytoskeleton. At the $10 \mu \mathrm{M}$ dose used, SB203580 and $\mathrm{Y}$ 27632 have been shown to be highly specific for their corresponding targets, without significant crossinhibition or inhibition of a long list of other protein kinases. ${ }^{46}$ Therefore the involvement of p38MAPK and ROCK-I, notwithstanding the future discovery of new targets for the inhibitors, seems convincing at this stage. We could not find in the literature any direct investigation of possible interaction between ML-7 and ROCK-I, but there are several reports indicating that such is not the case. For instance, Y27632-sensitive stress fiber formation in endothelial cells was not affected by $10 \mu \mathrm{M} \mathrm{ML}$ 7. ${ }^{47}$ Y27632 and ML-7 caused different effects on stress fiber organization in human fibroblasts. ${ }^{48}$

This paper reports data on two epithelial cell types stressed with a single type of stimulus. However, as observed here, apoptotic blebs displayed features similar to those induced by varied stimuli in several other cell types including endothelial, ${ }^{16}$ neuronal, ${ }^{38}$ lymphoid ${ }^{14}$ and fibroblasts. ${ }^{12,14,17,37}$ These features included temporal association with cell contraction in the release phase of apoptotic execution, ${ }^{9}$ early formation, irregular growth, transient nature, independence of calcium rises or ATP depletion, and dependency on the activity of kinases p38MAPK, ROCK-I and MLCK. On the other hand, the chronology of necrotic changes in HeLa and Clone 9 cells was remarkably similar to that described in LLC-PK1 cells ${ }^{25}$ and in renal epithelial cells. ${ }^{49}$

The possible existence of a specific structure that ensures controlled bleb growth suggests that blebbing may play a specific role in cell physiology or pathology. Considering available evidence, one such role may be the regulation of intracellular pressure. Firstly, normal cells and necrotic blebbing cells appear to display similar intracellular pressure $^{22}$ despite the fact that the latter are subject to large sodium and water overloads, which in Clone 9 liver cells and more recently in astrocytes have been linked to activation of nonselective cation channels. ${ }^{19,50}$ During swelling, the geometry of the cell body remains stable, with gained fluid being diverted to the blebs. In turn, these blebs grow and detach, allowing the cell to discard unwanted volume without major structural changes. Also, maintaining a relative narrow diameter at the neck may be requisite for efficient shedding. As the number of blebs displayed vary greatly between individual cells but growth rate does not, it could be hypothesized that during the NVI, cells regulate their internal pressure by expressing variable numbers of blebs. This is supported by the experiment illustrated in Figure 4d, where spontaneous membrane permeabilization, with its expected impact on intracellular pressure because of Donnan forces, was accompanied by the budding of new blebs. In this sense, bleb growth and shedding may be seen as an adaptive device to decrease cell volume, analogous to but mechanistically different from the regulatory volume decrease response. Noteworthy, during early exposure to lethal insults such as hydrogen peroxide, Fas ligand, TNF $\alpha$ or staurosporine, cells lose most of their major osmolytes (potassium, chloride and taurine) by AVD. If sodium overload occurs after the cells have exhausted their supply of dispensable osmolytes, volume will only be discarded by the $\mathrm{Na}^{+} / \mathrm{K}^{+}$ATPase or, in the absence of ATP, by growth and shedding of blebs. This putative mechanism may be at work in vivo, as ultrastructural studies in pathological thyroid glands show that detached blebs are phagocytosed by nearby cells. ${ }^{45}$ In apoptosis, blebbing is followed by AVD, a response that decreases intracellular pressure as judged by the collapsed appearance of blebs in Figure $5 \mathrm{e}$ and $\mathrm{f}$. It is possible then that dynamic blebbing allows fine control of pressure during cytoskeletal retraction but is no longer required when intracellular pressure goes down in AVD. Validation of such a hypothesis would require direct estimation of intracellular pressure during both apoptotic and necrotic blebbing.

\section{Materials and Methods}

\section{Cell culture}

HeLa cells were cultured on glass coverslips in 12-well plates with MEM medium supplemented with $10 \%$ fetal bovine serum (FBS) at $37^{\circ} \mathrm{C}$ under $95 \%$ air $/ 5 \% \mathrm{CO}_{2}$ for $24-72 \mathrm{~h}$ until experimental use. For HeLa cells stably transfected with the gene coding for firefly luciferase, the above medium was supplemented with $500 \mu \mathrm{g} / \mathrm{ml} \mathrm{G} 418$. The luciferase gene, luct, was excised from the pGL3 control vector (Promega, Madison, WI, USA) using $\mathrm{Ncol}$ and $\mathrm{Xbal}$. The $\mathrm{Ncol}$ site was blunted to be ligated into EcoRV-Xbaldigested pOPRSVI/MCS (STRATAGENE, La Jolla, CA, USA) to construct pOPRSVI/Luc+. To establish the luciferase expressing HeLa cells, the pOPRSVI/Luc+ plasmid was transfected using Effectine transfection reagent (Qiagen, Valencia, CA, USA), followed by the selection with $1 \mathrm{mg} /$ ml G418 for 10-14 days. G418-resistant colonies were cloned and screened by fluorescence microscopy with antiluciferase antibody (Promega). Clone 9 cells were grown on glass coverslips in $35 \mathrm{~mm}$ dishes with DMEM medium supplemented with $10 \% \mathrm{FBS}$ at $37^{\circ} \mathrm{C}$ under $95 \%$ air $/ 5 \% \mathrm{CO}_{2}$ for $24-72 \mathrm{~h}$ until experimental use.

\section{Chemicals}

Fluo-3 AM, pluronic acid, and di-4-ANEPPS and di-8-ANEPPS were from Molecular Probes (Eugene, OR, USA). ML-7, SB203580, Y-27632, PD150606 and z-VAD-fmk were from Calbiochem (La Jolla, CA, USA). Tissue culture reagents and standard chemicals were from Sigma (St. Louis, MO, USA).

\section{Volume, ATP and calcium measurements}

Experiments were carried out at room temperature $\left(26-29^{\circ} \mathrm{C}\right)$ in $\mathrm{Krebs}$ Ringer Hepes buffer (KRH; $136 \mathrm{mM} \mathrm{NaCl}, 10 \mathrm{mM}$ Hepes, $4.7 \mathrm{mM}$. KCl, $1.25 \mathrm{mM} \mathrm{MgSO}_{4}, 1.25 \mathrm{mM} \mathrm{CaCl}_{2}, \mathrm{pH}$ 7.4). Assays with both HeLa and Clone 9 cells have shown that at this temperature the chronology of ATP depletion, necrotic bleb onset and release of lactate dehydrogenase (LDH) do not differ significantly from those measured at $37^{\circ} \mathrm{C}$ (Castro $\mathrm{J}$ and Barros LF, unpublished data). For bleb volume measurements, HeLa cells 
were imaged under $\times 40$ phase-contrast or DIC optics every 20 s using a Nikon Eclipse TE300 inverted microscope equipped with a CCD camera (C2400, Hamamatsu Photonics, Hamamatsu, Japan) and an image enhancer (DRS 3000, Hamamatsu Photonics). The images were grabbed by a frame grabber installed in a PC at a resolution of $640 \times 400$. Bleb volumes were estimated automatically by using an image-analysing software, as described previously. ${ }^{51}$ Bleb volume in Clone 9 cells was estimated with a Zeiss LSM 5 Pascal confocal microscope by performing every $10 \mathrm{~min}$ a series of six $2 \mu \mathrm{m}$-thick optical sections separated by $3 \mu \mathrm{m}$ in cells stained with $1 \mu \mathrm{g} / \mathrm{ml}$ di-4-ANEPPS or $5 \mu \mathrm{g} / \mathrm{ml}$ di-8-ANEPPS. The dyes were imaged at $543 \mathrm{~nm}$ excitation and $560-615 \mathrm{~nm}$ emission. For every stack, the largest section was taken as best representative of the maximum diameter of the bleb. Volume was then calculated assuming sphericity. Measurements of intracellular ATP were carried out with a modification of a method described elsewhere. ${ }^{52}$ Glass coverslips with HeLa cells expressing luciferase were briefly washed with $\mathrm{KRH}$ and then placed in a $10 \mathrm{~mm}$ plastic cup containing $0.5 \mathrm{ml} \mathrm{KRH}$, which was introduced in a Lumi-counter 2500 (Microtech Niti-On, Japan). Luminiscence was recorded in real time by integrating photon counts over $20 \mathrm{~s}$. Samples were equilibrated with $100 \mu \mathrm{M}$ luciferine (Promega) for 10$20 \mathrm{~min}$ until the signal stabilised. In control experiments, high concentrations of hydrogen peroxide were found to increase luminescence in the absence of cells. This precluded real-time measurements and made necessary the indirect protocol described in Results. A calibration in permeabilized cells gave a $K_{d}$ of $1.55 \pm 0.15 \mathrm{mM}(n=5)$ and basal [ATP] was estimated at $1.25 \pm 0.15 \mathrm{mM}(n=5)$. Fluo-3 calcium fluorescence was imaged with the confocal microscope as described previously. ${ }^{19}$ The validity of this method to estimate calcium in HeLa cells was demonstrated using a $\mathrm{Mn}^{2+}$ quenching protocol. ${ }^{53}$ Fluo-3 signal in the presence of the heavy metal was equivalent to $94 \pm 16 \mathrm{nM}(n=11)$, a value not significantly different from the $100 \mathrm{nM}$ predicted; assuming a $K_{d}$ for $\mathrm{Ca}^{2+}$ binding to Fluo-3 of $390 \mathrm{nM}$, basal calcium in HeLa cells was estimated at $98 \pm 12 \mathrm{nM}(n=11)$.

\section{Caspase activity and cell viability measurements}

Activities of caspase- 1 and caspase- 3 were measured by using a fluorometric assay. ${ }^{54}$ In brief, cultured cells were washed with PBS at $4^{\circ} \mathrm{C}$, detached from the substrate by pipetting, harvested by centrifugation (1000 rpm) for $5 \mathrm{~min}$ at $4^{\circ} \mathrm{C}$, and treated with the fluorometric caspase assay system (Promega). The cell pellet was resuspended in $10 \mu \mathrm{l}$ hypotonic cell lysis buffer and centrifuged at $14,000 \mathrm{rpm}$ for $5 \mathrm{~min}$ at $4^{\circ} \mathrm{C}$. The supernatant was preincubated for $30 \mathrm{~min}$ at $37^{\circ} \mathrm{C}$ with $32 \mu \mathrm{l}$ of caspase assay buffer, $2 \mu \mathrm{l}$ DMSO, $10 \mu \mathrm{l}$ of $100 \mathrm{mM}$ DTT and deionized water to a final volume of $98 \mu \mathrm{l}$. The samples were incubated with $2 \mu \mathrm{l}$ of the $2.5 \mathrm{mM}$ caspase- 1 substrate (Ac-YVAD-AMC) or the $2.5 \mathrm{mM}$ caspase3 substrate (Ac-DEDV-AMC) for $1 \mathrm{~h}$ at $37^{\circ} \mathrm{C}$. Fluorescence intensity was measured with the Multiskan microplate reader (Labsystems, Helsinki, Finland). The specificity of the assay was verified by adding $2.5 \mathrm{mM}$ of the caspase-1 inhibitor (Ac-YVAD-CHO) or the caspase-3 inhibitor (Ac-DEDV$\mathrm{CHO}$ ) to the mixture. Cell viability was assessed by mitochondrial dehydrogenase activity using the colorimetric MTT assay, as described previously. ${ }^{10} \mathrm{PI}$ uptake was imaged at $2 \mu \mathrm{g} / \mathrm{ml}$. LDH release was estimated by spectrophotometry using a Sigma (St. Louis, MO, USA) kit as described. ${ }^{19}$

\section{Scanning electron microscopy}

The hydrated cultured cells were prefixed with a mixture of glutaraldehyde and formaldehyde ${ }^{55}$ followed by $1 \%$ osmium tetraoxide. After the dehydration by alcohol, the specimens were dried using the critical point drying method. The surface of the specimens was then covered with a thin layer of gold using an ion coater, IB-3 (EIKO Engineering, Tokyo, Japan). Observations were done by a Hitachi S-800 scanning electron microscope operating at $20 \mathrm{kV}$.

\section{Statistical analysis}

Data are presented as means \pm s.e. $\mathrm{m}(n)$. Differences between data sets were assessed with Student's $t$-test or ANOVA followed by NewmanKeuls ad hoc test. Differences were considered significant at $P<0.05$. Nonlinear regression analyses were carried out using SigmaPlot (SPSS Inc.). Frequency distributions were fitted to the Gaussian function

$$
y=a e^{-0.5 \cdot\left(\left(x-x_{0}\right) / b\right)^{2}}
$$

Standard errors of the means associated to the fitted parameters are shown as given by the software.

\section{Acknowledgements}

We are grateful to $K$ Shigemoto and S Sabirova for their technical assistance. We acknowledge a visiting Professorship from the Japanese Government to LFB. This work was supported by Grant-in-Aid for Scientific Research (A) from the Ministry of Education, Culture, Sports, Science and Technology of Japan (to YO), and also by Fondecyt 1020648 and 7020 Chile (to LFB). We also thank Fundación Andes, Chile, for an Equipment Grant to CECS. CECS is a Millenium Science Institute.

\section{References}

1. Boss J (1955) Mitosis in cultures of new tissues: IV. The cell surface in late anaphase and the movements of ribonucleoproteins. Exp. Cell Res. 8: 181191

2. Porter K, Prescott D and Frye $J$ (1973) Changes in surface morphology of Chinese hamster ovary cells during the cell cycle. J. Cell Biol. 57: 815-836

3. Albrecht-Buehler $\mathrm{G}$ (1982) Does blebbing reveal the convulsive flow of liquid and solutes through the cytoplasmic meshwork?. Cold Spring Harb. Symp. Quant. Biol. 46(Part 1): 45-49

4. Cunningham CC (1995) Actin polymerization and intracellular solvent flow in cell surface blebbing. J. Cell Biol. 129: 1589-1599

5. Trinkaus JP (1980) Formation of protrusions of the cell surface during tissue cell movement. Prog. Clin. Biol. Res. 41: 887-906

6. Casciola-Rosen L, Rosen A, Petri M and Schlissel M (1996) Surface blebs on apoptotic cells are sites of enhanced procoagulant activity: implications for coagulation events and antigenic spread in systemic lupus erythematosus. Proc. Natl. Acad. Sci. USA 93: 1624-1629

7. Segundo C, Medina F, Rodriguez C, Martinez-Palencia R, Leyva-Cobian F and Brieva JA (1999) Surface molecule loss and bleb formation by human germinal center B cells undergoing apoptosis: role of apoptotic blebs in monocyte chemotaxis. Blood 94: 1012-1020

8. Gores GJ, Herman B and Lemasters JJ (1990) Plasma membrane bleb formation and rupture: a common feature of hepatocellular injury. Hepatology 11: 690-698

9. Mills JC, Stone NL and Pittman RN (1999) Extranuclear apoptosis. The role of the cytoplasm in the execution phase. J. Cell Biol. 146: 703-708

10. Maeno E, Ishizaki $Y$, Kanaseki T, Hazama A and Okada Y (2000) From the cover: normotonic cell shrinkage because of disordered volume regulation is an early prerequisite to apoptosis. Proc. Natl. Acad. Sci. USA 97: 9487-9492

11. Okada Y, Maeno E, Shimizu T, Dezaki K, Wang J and Morishima S (2001) Receptor-mediated control of regulatory volume decrease (RVD) and apoptotic volume decrease (AVD). J. Physiol. 532: 3-16 
12. Coleman ML, Sahai EA, Yeo M, Bosch M, Dewar A and Olson MF (2001) Membrane blebbing during apoptosis results from caspase-mediated activation of ROCK I. Nat. Cell Biol. 3: 339-345

13. Leverrier $Y$ and Ridley AJ (2001) Apoptosis: caspases orchestrate the ROCK 'n' bleb. Nat. Cell Biol. 3: E91-E93

14. Sebbagh M, Renvoize C, Hamelin J, Riche N, Bertoglio J and Breard J (2001) Caspase-3-mediated cleavage of ROCK I induces MLC phosphorylation and apoptotic membrane blebbing. Nat. Cell Biol. 3: 346-352

15. Huot J, Houle F, Marceau F and Landry J (1997) Oxidative stress-induced actin reorganization mediated by the p38 mitogen-activated protein kinase/heat shock protein 27 pathway in vascular endothelial cells. Circ. Res. 80: 383-392

16. Huot J, Houle F, Rousseau S, Deschesnes RG, Shah GM and Landry J (1998) SAPK2/p38-dependent F-actin reorganization regulates early membrane blebbing during stress-induced apoptosis. J. Cell Biol. 143: 1361-1373

17. Deschesnes RG, Huot J, Valerie $\mathrm{K}$ and Landry J (2001) Involvement of p38 in apoptosis-associated membrane blebbing and nuclear condensation. Mol. Biol. Cell. 12: 1569-1582

18. Jewell SA, Bellomo G, Thor H, Orrenius S and Smith M (1982) Bleb formation in hepatocytes during drug metabolism is caused by disturbances in thiol and calcium ion homeostasis. Science 217: 1257-1259

19. Barros LF, Stutzin A, Calixto A, Catalán M, Castro J, Hetz C and Hermosilla T (2001) Non-selective cation channels as effectors of free radical-induced rat liver cell necrosis. Hepatology 33: 114-122

20. Barros LF, Hermosilla T and Castro J (2001) Necrotic volume increase and the early physiology of necrosis. Comp. Biochem. Physiol. A Mol. Integr. Physiol. 130: 401-409

21. Chen $\mathrm{J}$ and Wagner MC (2001) Altered membrane-cytoskeleton linkage and membrane blebbing in energy-depleted renal proximal tubular cells. Am. J. Physiol. Renal Physiol. 280: F619-F627

22. Doctor RB, Zhelev DV and Mandel LJ (1997) Loss of plasma membrane structural support in ATP-depleted renal epithelia. Am. J. Physiol. 272: C439C449

23. Jurkowitz-Alexander MS, Altschuld RA, Hohl CM, Johnson JD, McDonald JS, Simmons TD and Horrocks LA (1992) Cell swelling, blebbing, and death are dependent on ATP depletion and independent of calcium during chemical hypoxia in a glial cell line (ROC-1). J. Neurochem. 59: 344-352

24. Li Y, Liu J and Zhan X (2000) Tyrosine phosphorylation of cortactin is required for $\mathrm{H}_{2} \mathrm{O}_{2}$-mediated injury of human endothelial cells. J. Biol. Chem. 275: 37187-37193

25. Scott JA, Fischman AJ, Homcy CJ, Fallon JT, Khaw BA, Peto CA and Rabito CA (1989) Morphologic and functional correlates of plasma membrane injury during oxidant exposure. Free Radical Biol. Med. 6: 361-367

26. Hampton MB and Orrenius S (1997) Dual regulation of caspase activity by hydrogen peroxide: implications for apoptosis. FEBS Lett. 414: 552-556

27. Hinshaw DB, Sklar LA, Bohl B, Schraufstatter IU, Hyslop PA, Rossi MW, Spragg RG and Cochrane CG (1986) Cytoskeletal and morphologic impact of cellular oxidant injury. Am. J. Pathol. 123: 454-464

28. Wang X, Martindale JL, Liu Y and Holbrook NJ (1998) The cellular response to oxidative stress: influences of mitogen-activated protein kinase signalling pathways on cell survival. Biochem. J. 333: 291-300

29. Leist M, Single B, Castoldi AF, Kuhnle S and Nicotera P (1997) Intracellular adenosine triphosphate (ATP) concentration: a switch in the decision between apoptosis and necrosis. J. Exp. Med. 185: 1481-1486

30. Lee $Y J$ and Shacter $E(2000)$ Hydrogen peroxide inhibits activation, not activity, of cellular caspase-3 in vivo. Free Radical Biol. Med. 29: 684-692

31. Bellomo $G$ and Orrenius $S$ (1985) Altered thiol and calcium homeostasis in oxidative hepatocellular injury. Hepatology $5:$ 876-882

32. Ikeda M, Ariyoshi H, Sakon M, Kambayashi J, Yoshikawa N, Shinoki N Kawasaki T and Monden M (1998) A role for local calcium gradients upon hypoxic injury in human umbilical vein endothelial cells (HUVEC). Cell Calcium 24: $49-57$

33. Miyoshi H, Umeshita K, Sakon M, Imajoh-Ohmi S, Fujitani K, Gotoh M, Oiki E, Kambayashi J and Monden M (1996) Calpain activation in plasma membrane bleb formation during tert-butyl hydroperoxide-induced rat hepatocyte injury. Gastroenterology 110: 1897-1904
34. Waters SL, Sarang SS, Wang KK and Schnellmann RG (1997) Calpains mediate calcium and chloride influx during the late phase of cell injury. J. Pharmacol. Exp. Ther. 283: 1177-1184

35. Zheng LM, Zychlinsky A, Liu CC, Ojcius DM and Young JD (1991) Extracellular ATP as a trigger for apoptosis or programmed cell death. J. Cell Biol. 112: 279288

36. Janicke RU, Sprengart ML, Wati MR and Porter AG (1998) Caspase-3 is required for DNA fragmentation and morphological changes associated with apoptosis. J. Biol. Chem. 273: 9357-9360

37. McCarthy NJ, Whyte MK, Gilbert CS and Evan GI (1997) Inhibition of Ced-3/ ICE-related proteases does not prevent cell death induced by oncogenes, DNA damage, or the Bcl-2 homologue Bak. J. Cell Biol. 136: 215-227

38. Mills JC, Stone NL, Erhardt J and Pittman RN (1998) Apoptotic membrane blebbing is regulated by myosin light chain phosphorylation. J. Cell Biol. 140: 627-636

39. Torgerson RR, McNiven MA (1998) The actin-myosin cytoskeleton mediates reversible agonist-induced membrane blebbing. J. Cell Sci. 111: 2911-2922

40. Cunningham CC (1995) Actin polymerization and intracellular solvent flow in cell surface blebbing. J. Cell Biol. 129: 1589-1599

41. Nieminen AL, Gores GJ, Wray BE, Tanaka Y, Herman B and Lemasters JJ (1988) Calcium dependence of bleb formation and cell death in hepatocytes. Cell Calcium 9: 237-246

42. Jurkowitz-Alexander MS, Altschuld RA, Hohl CM, Johnson JD, McDonald JS, Simmons TD et al. (1992) Cell swelling, blebbing, and death are dependent on ATP depletion and independent of calcium during chemical hypoxia in a glial cell line (ROC-1). J. Neurochem. 59: 344-352

43. Laster SM and Mackenzie Jr JM (1996) Bleb formation and F-actin distribution during mitosis and tumor necrosis factor-induced apoptosis. Microsc. Res. Tech. 34: 272-280

44. Pitzer F, Dantes A, Fuchs T, Baumeister W and Amsterdam A (1996) Removal of proteasomes from the nucleus and their accumulation in apoptotic blebs during programmed cell death. FEBS Lett. 394: 47-50

45. Zeligs JD and Wollman SH (1977) Ultrastructure of blebbing and phagocytosis of blebs by hyperplastic thyroid epithelial cells in vivo. J. Cell Biol. 72: 584-594

46. Davies SP, Reddy H, Caivano M and Cohen P (2000) Specificity and mechanism of action of some commonly used protein kinase inhibitors. Biochem. J. 351: 95-105

47. Wang $P$, Verin $A D$, Birukova A, Gilbert-McClain LI, Jacobs K and Garcia JG (2001) Mechanisms of sodium fluoride-induced endothelial cell barrier dysfunction: role of MLC phosphorylation. Am. J. Physiol. Lung Cell Mol. Physiol. 281: L1472-L1483

48. Katoh K, Kano Y, Amano M, Kaibuchi K and Fujiwara K (2001) Stress fiber organization regulated by MLCK and Rho-kinase in cultured human fibroblasts. Am. J. Physiol. Cell Physiol. 280: C1669-C1679

49. Kreisberg JI, Mills JW, Jarrell JA, Rabito CA and Leaf A (1980) Protection of cultured renal tubular epithelial cells from anoxic cell swelling and cell death. Proc. Natl. Acad. Sci. USA 77: 5445-5447

50. Dong Z, Venkatachalam MA, Weinberg JM, Saikumar P and Patel Y (2001) Protection of ATP-depleted cells by impermeant strychnine derivatives: implications for glycine cytoprotection. Am. J. Pathol. 158: 1021-1028

51. Morishima S, Kida H, Ueda S, Chiba T, Okada Y (1998). Water movement during cell volume regulation. In Cell Volume Regulation. The Molecular Mechanism and Volume Sensing Machinery. Okada Y (ed). (Amsterdam: Elsevier), pp. 209-212

52. Maechler $\mathrm{P}$, Wang $\mathrm{H}$ and Wollheim $\mathrm{CB}$ (1998) Continuous monitoring of ATP levels in living insulin secreting cells expressing cytosolic firefly luciferase. FEBS Lett. 422: 328-332

53. Nadal A, Fuentes E and McNaughton PA (1996) Albumin stimulates uptake of calcium into subcellular stores in rat cortical astrocytes. J. Physiol. (London). 492: $737-750$

54. Thornberry NA (1994) Interleukin-1 beta converting enzyme. Methods Enzymol. 244: 615-631

55. Karnovsky MJ (1965) A formaldehyde-gluteraldehyde fixative of high osmolality for use in electron microscopy. J. Cell Biol. 27: 137A 